\title{
Evaluation of physical properties of Errandi-acrylic union fabrics
}

\section{Sunita Boruah*}

Assistat Professor, Department of Fashion Design and Technology, Assam Women's University, Jorhat-785004 (Assam), India

\section{B. Baishya Kalita}

Professor, Department of Textiles and Apparel designing, College of Community Science, Assam Agricultural University, Jorhat-785013 (Assam), India

*Corresponding author. E-Mail: sunitaboruah182@gmail.com

\begin{abstract}
:
Errandi silk has a potential of emerging as "A silk of the new millennium". The experimental finding provides information on physical properties as well as subjective evaluations of Errandi silk -Acrylic union fabrics with twill and herringbone weave. The count and diameter of errandi silk fibre were higher than acrylic fibre and in case of woven fabrics, herringbone weave were found to have maximum value in cloth covers, weight and thickness. A comparative subjective evaluation was done based on fabric quality by the panel of 100 respondents. 100 per cent respondent opined that all the woven samples have good appearance, soft in hand and smooth in texture. It was observed that cent percent of respondents found errandi-acrylic blended union fabrics with twill and herringbone weaves were high in lustre. The costs of blended yarns and the cost of union fabrics of different proportion were got reduced in comparison to that of 100 per cent errandi-silk yarn (Rs.3000.00/kg) and controlled errandi silk fabrics (Rs.985.00/mt.). Based on the aesthetic properties such as handle, appearance, texture and lustre and considering the cost of twill and herringbone errandi-acrylic fabrics were suitable for production of fashionable wear. Thus, the newly designed Errandi silk with Acrylic union fabrics are unique, a new venture for the textile industry and Ericulturists.
\end{abstract}

Keyword: Acrylic, Entrepreneur, Errandi silk, Twill structured, Union fabrics

\section{Article Info}

DOI:10.31018/jans.v10i3.1816

Received: June 30, 2018

Revised: July 16, 2018

Accepted: July 30, 2018

\section{How to Cite}

Boruah, S. et al. (2018)

Evaluation of physical properties of Errandiacrylic union fabrics. Journal of Applied and Natural Science, 10(3): $925-930$

\section{INTRODUCTION}

The economic development of a nation depends on its industrial development. The industrial development is on the entrepreneur competencies of the people. Hence, the concept of building entrepreneurship promotion is need of the hour (Bai, 2017). The market trends more and more point out for the globalization of the production chains, merchandising and for small market niches for high added value products. The emotional satisfaction of the clothing fashion consumers is one of the largest concerns of the designer, as well as creating profitable products for the industry. Handloom sector plays an important role in the Indian economy in the context of employment generation and the economic development of India. Handloom units are also very important for welfare resources. Handlooms, a traditional wear in India has lost its significance slowly with the advent of low cost and eye catchy synthetic materials. However, with the notion of 'Make in India' campaign and the planning commission giving it a due place in the economic sector under other priority sectors is regaining its unique identity. USA, UK, Germany and France are among the top ten countries to where the Indian handloom products exported. The Indian government launched Handloom brand to ensure its uniqueness, flexibility of production, openness to innovations, adaptability. The number of handloom weaver households decreased in the third handloom census compared to that of second. So as to support weavers the Indian government launched schemes and initiated exhibitions, crafts museum, trade facilitation centre and Ecommerce. Market research on the Handlooms identified the need for publicity, availability, Handloom designer dresses and awareness campaigns on a large scale for its sustenance (Vyshnavi and Nair, 2017). People can organize these units to increase their income levels and quality of life. So these can help in reducing poverty in the country. A handloom style is a manifest expression of the world of the artisan. Each type represents a particular people or group of people in one place at a point in time. This difference in styles patterns or motifs used, ground fabric and yarns used (Chakraborty and Ghosh, 2016).

In the field of textiles the present era can truly be called the era of blending. Blending of fibres is usually made with different fibres having dissimi- 
larity in their properties, with a view to achieving or improving certain characters of the yarn or its processing performances. Fabric produced from the blended yarn might have better characteristics than the in a fabric produced from a single fibre. The blending of fibre is done to develop drape properties, comfortability, durability and many other properties of the fabric products (Prakash et al., 2012). Errandi silk has a potential of emerging as "A silk of the new millennium", providing excellent dimension of scope in design development and produced fashionable dresses with special properties to produce abundant finished products. It's possesses excellent thermal properties and offer tremendous blending possibilities with other natural fiber such as silks, wool, cotton, jute and synthetic fibers (Somashekhar, 2003). Acrylic can be thought of as artificial wool. It is made from the unlikely combination of coal, air, water, oil, and limestone (Textile School, 2018). Discovery of different types of man-made fibres and the use of them in staple form have opened immense scope to produce textile having diverse properties and visual appeal to cater the taste of all kinds of people. Jurisdiction selection of fibre for blending can increase the possibilities of newer application of these fibres along with different kinds of products. The survival of textile industry depends primarily on the fabric quality as well as fashion trends meet the national as well as international demands. Diversification in the product can be brought about at various stages viz., yarn, fabric, design, fashion and style. These Errandi silk is most suitable for handloom sector and boon for entrepreneur because it is compatible to interweave with natural as well as manmade yarns to produce designer fabrics at a reasonable price.

Therefore, the present study was undertaken with the aim of producing Errandi union silk fabrics for variegated dress materials with twill and herringbone weave using Errandi-Acrylic blended yarn as weft direction.

\section{MATERIALS AND METHODS}

The errandi silk and acrylic fibres were collected from Industry, Fabric plus Pvt. Ltd. Guwahati, Assam, India.

The Fibre were tested for Physical properties viz. Fibre count (VIBROSCOP-400- ASTM D: 3822) and diameter (Projection- IS: 744-1977)were studied. The yarns were tested for yarn count (Beesley balance), yarn density (Electronic Balances- ASTM, 1970) and twist per inch (Twist Tester- IS: 832 "1985"). Developed fabrics were tested for fabric cover factor (Beesley balance Model No. - PSB-167), fabric weight (Electronic balance 200B- IS: 1964: 1970) and fabric thickness (Thickness Tester- B.S. 2544:954).

Prior to the testing, all the samples (fibre, yarn and fabric) were conditioned to the moisture equi- librium in standard atmosphere at $65 \pm 2$ per cent relative humidity and $27 \pm 2^{\circ} \mathrm{C}$ temperature in a conditioning chamber (IS: 6359- 1971).

\section{Blending and spinning of fibers}

Segregation of cocoon: After collecting, errandi cocoons (Philosomia ricini) are segregated manually. The selected cocoons are kept for further processing.

Degumming: Silk contains $10-15 \%$ of sericin which is to be removed either by boiling with soap water or sodium carbonate followed by hydro extraction (removal of excess water). This process reduces the sericin content to $2-3 \%$ which is optimum for further opening and carding. This process also opens the cocoon to a fluffy form.

Cocoon opening: The degummed cocoons are opened in cocoon opener to form fibre lap/sheet which help for further processing.

Circular dressing: In these process fibres laps are subjected to circular dressing, where short fibres are separated from longer one. After that the fibres were cut into a definite length ranging from $70-80 \mathrm{~mm}$.

Carding: The eri silk fibres were cut into $55.20 \mathrm{~cm}$. It was then thoroughly mixed with modal and acrylic fiber in required ratio and fed into carding machine to convert the fiber into sliver form known as carded eri silk top and modal and acrylic top respectively.

Drawing frame: In drawing frame combines 7 slivers into one. Repeated drawing increases the quality of the sliver allowing for finer counts to be spun.

Simplex: Simplex is a long and narrow bundle of fiber. It is the process of making yarn from the sliver on other raw fibres. Simplex make bobbin with roving of conical shape.

Ring spinning: In this process, the roving was further drawn 25-30 times (which depends on final fineness of yarn to be spun) and required twist is inserted in the yarn for finally obtaining the required fine yarn in the form of condensed package.

Constructional details of woven fabrics: In the present study, an attempt was made to construct the union fabrics by using blended yarns in weft direction and $100 \%$ errandi silk yarn in warp direction with two different weaves structure i.e. twill and herringbone weaves on handloom (Fly shuttle). Constructional details of woven fabrics were presented in Table 1.

Subjective Evaluation of woven fabrics: Assessment of aesthetic and handle properties of Errandi union fabrics were performed by assessing 100 respondents from different age, education, and occupational groups. Some important properties, such as handle (Rating scale:-3-Soft, 2 -Crisp and 1- Stiffs), appearance ( Rating scale:-3Good, 2-Fair and 1-Poor), texture (Rating scale:2-Smooth and 1-Rough) and lustre( Rating scale : 
- 3-High, 2- Moderate and 1- Low) were assessed by the respondents with the help of interview schedule. Further, the results were expressed in terms of percentages.

\section{RESULTS AND DISCUSSION}

Fibre and yarn test results: The fibres and blended yarns are tested for physical properties and the results are shown in Table 2 . Length is the most important property of a fiber. The length of fiber is directly related to its spinning performance (Gupta et al. 2000). It is evident from the Table that the fibre length of acrylic fibres ranged from $126 \mathrm{~mm}$ to $04 \mathrm{~mm}$ with the mean fibre length of $55.27 \mathrm{~mm}$ and endi- silk fibre was spun from the cut cocoon fibre exhibiting the range from $136 \mathrm{~mm}$ to $04 \mathrm{~mm}$ with the mean fiber length of $55.20 \mathrm{~mm}$.
This fibre length of silk was suitable for blending as it was similar to average length of acrylic fibre used in the study. The count of the fibre directly affects the properties of resultant yarn and fabric. The endi silk had maximum count (0.55tex) and diameter (17.45micron) than acrylic fiber. Rieter (2018) mentioned that in general fiber count increases, resistance to bending decreases. Fiber diameter decides a fabric's performance and hand (how it feels). NPTEL (2014) reported that large diameter fibers are crisp, rough and stiff and fine fibers are soft and pliable and fabric made of them which can be draped more easily.

Although in case of yarn, controlled endi silk and higher percentage of endi silk blended yarn had more twist than controlled acrylic and their blended. It may be due to the effect of twist per inch

Table 1. Constructional details of woven fabrics.

\begin{tabular}{|c|c|c|c|c|c|c|c|}
\hline \multirow{2}{*}{$\begin{array}{l}\text { S. } \\
\text { N. }\end{array}$} & \multirow[t]{2}{*}{ Sample } & \multirow[t]{2}{*}{ Sample code } & \multirow[t]{2}{*}{ Weave } & \multicolumn{2}{|c|}{ Composition } & \multirow{2}{*}{$\begin{array}{l}\text { Reed } \\
\text { count }\end{array}$} & \multirow{2}{*}{$\begin{array}{l}\text { Loom } \\
\text { pick }\end{array}$} \\
\hline & & & & Warp \% & Weft $\%$ & & \\
\hline \multirow[t]{2}{*}{1} & Errandi $100 \%$ & ET & Twill & Errandi & Errandi & 80 & 69 \\
\hline & & $\mathrm{EH}$ & $\begin{array}{l}\text { Herringbone } \\
\text { Twill }\end{array}$ & $100 \%$ & $100 \%$ & 80 & 50 \\
\hline \multirow[t]{2}{*}{2} & Acrylic & AT & Twill & Acrylic & Acrylic & 60 & 62 \\
\hline & $100 \%$ & $\mathrm{AH}$ & $\begin{array}{l}\text { Herringbone } \\
\text { Twill }\end{array}$ & $100 \%$ & $100 \%$ & 60 & 48 \\
\hline \multirow[t]{2}{*}{3} & Union & EAT $70: 30$ & Twill & Errandi & Errandi- & 80 & 55 \\
\hline & $\begin{array}{l}\text { (Errandi- Acrylic } \\
70: 30 \text { ) }\end{array}$ & EAH 70:30 & $\begin{array}{l}\text { Herringbone } \\
\text { Twill }\end{array}$ & $100 \%$ & $\begin{array}{l}\text { Acrylic } \\
70: 30\end{array}$ & 80 & 50 \\
\hline \multirow[t]{2}{*}{4} & Union & EAT 50:50 & Twill & Errandi & Errandi- & 80 & 54 \\
\hline & $\begin{array}{l}\text { (Errandi- Acrylic } \\
50: 50 \text { ) }\end{array}$ & EAH 50:50 & $\begin{array}{l}\text { Herringbone } \\
\text { Twill }\end{array}$ & $100 \%$ & $\begin{array}{l}\text { Acrylic } \\
50: 50\end{array}$ & 80 & 46 \\
\hline \multirow[t]{2}{*}{5} & Union & EAT 30:70 & Twill & Errandi & Errandi- & 80 & 44 \\
\hline & $\begin{array}{l}\text { (Errandi- Acrylic } \\
30: 70 \text { ) }\end{array}$ & EAH 30:70 & $\begin{array}{l}\text { Herringbone } \\
\text { Twill }\end{array}$ & $100 \%$ & $\begin{array}{l}\text { Acrylic } \\
30: 70\end{array}$ & 80 & 44 \\
\hline
\end{tabular}

Table 2. Physical properties of the selected fibres and blended yarns.

\begin{tabular}{|c|c|c|c|c|c|c|c|c|}
\hline \multirow{2}{*}{$\begin{array}{l}\text { Physical Param- } \\
\text { eters }\end{array}$} & \multicolumn{2}{|l|}{ Fibres } & \multirow{2}{*}{$\begin{array}{l}\text { Physical Param- } \\
\text { eters }\end{array}$} & \multicolumn{5}{|l|}{ Yarns } \\
\hline & $\begin{array}{l}\text { Errandi } \\
\text {-silk }\end{array}$ & Acrylic & & $\begin{array}{l}\text { Errandi } \\
100 \%\end{array}$ & $\begin{array}{l}\text { Acrylic } \\
100 \%\end{array}$ & $\begin{array}{l}\text { EA } \\
70: 30\end{array}$ & $\begin{array}{l}\text { EA } \\
50: 50\end{array}$ & $\begin{array}{l}\text { EA } \\
30: 70\end{array}$ \\
\hline $\begin{array}{l}\text { Fibre length }(\mathrm{mm}) \\
\text { Maximum length }\end{array}$ & $\begin{array}{l}55.20 \\
136\end{array}$ & $\begin{array}{l}55.27 \\
126\end{array}$ & $\begin{array}{l}\text { Average } \quad \text { twist } \\
\text { (tpi) }\end{array}$ & 14.54 & 10.04 & 12.82 & 11.36 & 10.19 \\
\hline $\begin{array}{l}\text { Minimum length } \\
\text { Fibre Count(tex) }\end{array}$ & $\begin{array}{l}04 \\
0.55\end{array}$ & $\begin{array}{l}04 \\
0.27\end{array}$ & Density (g/cm3) & 2.08 & 2.68 & 2.39 & 2.44 & 2.71 \\
\hline $\begin{array}{l}\text { Fibre diameter } \\
\text { (microns) }\end{array}$ & 17.45 & 12.85 & & & & & & \\
\hline
\end{tabular}

\section{$E=$ Errandi silk, $A=$ Acrylic}

Table 3. Cloth cover factor, Weight and Thickness of the controlled and union fabrics of Twill and Herringbone weaves.

\begin{tabular}{|c|c|c|c|c|c|c|c|c|c|}
\hline \multirow{2}{*}{$\begin{array}{l}\text { Test Fab- } \\
\text { rics }\end{array}$} & \multicolumn{2}{|c|}{ Cloth Cover (Ne) } & \multirow{2}{*}{ Mean } & \multicolumn{2}{|c|}{$\begin{array}{c}\text { Total weight (gm/ } \\
\text { sq.mt) }\end{array}$} & \multirow{2}{*}{ Mean } & \multicolumn{2}{|c|}{ Thickness (mm) } & \multirow{2}{*}{ Mean } \\
\hline & $\begin{array}{c}\text { Twill } \\
\text { Weave }\end{array}$ & $\begin{array}{c}\begin{array}{c}\text { Herringbone } \\
\text { Weave }\end{array} \\
\end{array}$ & & $\begin{array}{c}\text { Twill } \\
\text { Weave }\end{array}$ & $\begin{array}{c}\text { Herringbone } \\
\text { Weave }\end{array}$ & & $\begin{array}{c}\text { Twill } \\
\text { Weave }\end{array}$ & $\begin{array}{c}\begin{array}{c}\text { Herringbone } \\
\text { Weave }\end{array} \\
\end{array}$ & \\
\hline $\begin{array}{l}\text { Errandi silk } \\
100 \%\end{array}$ & 12.48 & 12.55 & 12.51 & 159.10 & 158.69 & 158.89 & 0.52 & 0.52 & 0.52 \\
\hline Acrylic $100 \%$ & 12.72 & 12.81 & 12.66 & 154.03 & 153.95 & 153.99 & 0.51 & 0.53 & 0.52 \\
\hline EA 70/30 & 12.38 & 12.53 & 12.45 & 143.17 & 149.10 & 146.13 & 0.49 & 0.49 & 0.49 \\
\hline EA 50/50 & 13.43 & 13.59 & 13.51 & 143.17 & 145.16 & 144.16 & 0.48 & 0.49 & 0.48 \\
\hline EA 30/70 & 13.34 & 13.67 & 13.50 & 142.86 & 145.03 & 143.94 & 0.47 & 0.50 & 0.48 \\
\hline Mean & 12.83 & 12.96 & & 145.81 & 147.32 & & 0.48 & 0.50 & \\
\hline
\end{tabular}

$E=$ Errandi silk, $A=$ Acrylic 
Table 4. Respondents opinion on general appearance of woven fabrics (\%).

\begin{tabular}{|c|c|c|c|c|c|c|c|}
\hline Test fabric & Gener & Appe & rance (\%) & Test fabric & Gener & peara & $(\%)$ \\
\hline Twill weave & Good & Fair & Poor & Herringbone Twill Weave & Good & Fair & Poor \\
\hline ET & 40 & 60 & - & $\mathrm{EH}$ & 100 & - & - \\
\hline AT & 100 & - & - & $\mathrm{AH}$ & 100 & - & - \\
\hline EAT 70:30 & 100 & - & - & EAH 70:30 & 100 & - & - \\
\hline EAT 50:50 & 100 & - & - & EAH 50:50 & 100 & - & - \\
\hline EAT $30: 70$ & 100 & - & - & EAH 30:70 & 100 & - & - \\
\hline
\end{tabular}

$E=$ Errandi silk, $A=$ Acrylic, $T=$ Twill, $H=$ Herringbone

Table 5. Respondents opinion about the lustre of the woven fabric (\%).

\begin{tabular}{llllllll}
\hline Test Fabric & \multicolumn{2}{l}{ Lustre (\%) } & \multicolumn{3}{l}{ Test Fabric } & \multicolumn{2}{l}{ Lustre (\%) } \\
\hline Twill weave & High & moderate & Low & Herringbone Twill Weave & High & moderate & Low \\
\hline ET & 30 & 70 & - & EH & 39 & 61 & - \\
AT & 34 & 66 & - & AH & 36 & 64 & - \\
EAT 70:30 & 40 & 60 & - & EAH 70:30 & 39 & 61 & - \\
EAT 50:50 & 38 & 62 & - & EAH 50:50 & 37 & 63 & - \\
EAT 30:70 & 32 & 68 & - & EAH 30:70 & 34 & 66 & - \\
\hline
\end{tabular}

$E=E r r a n d i$ silk, $A=$ Acrylic, $T=$ Twill, $H=$ Herringbone

Table 6. Respondents opinion regarding handle of woven fabrics (\%).

\begin{tabular}{lccccccc}
\hline Test Fabric & \multicolumn{3}{c}{ Handle } & Test Fabric & \multicolumn{3}{c}{ Handle } \\
\hline Twill weave & Soft & Crisp & Stiffs & Herringbone Twill Weave & Soft & Crisp & Stiffs \\
\hline ET & 100 & - & - & EH & 100 & - & - \\
AT & 100 & - & - & AH & 100 & - & - \\
EAT 70:30 & 100 & - & - & EAH 70:30 & 100 & - & - \\
EAT 50:50 & 100 & - & - & EAH 50:50 & 100 & - & - \\
EAT 30:70 & 100 & - & - & EAH 30:70 & 100 & - & - \\
\hline
\end{tabular}

$E=$ Errandi silk, $A=$ Acrylic, $T=$ Twill, $H=$ Herringbone

Table 7. Respondents opinion on texture of woven fabrics (\%).

\begin{tabular}{lccccc}
\hline Test Fabric & \multicolumn{2}{c}{ Texture } & \multicolumn{2}{c}{ Test Fabric } & \multicolumn{2}{c}{ Texture } \\
\hline Twill weave & Smooth & Rough & Herringbone Twill Weave & Smooth & Rough \\
\hline ET & 100 & - & EH & 100 & - \\
AT & 100 & - & AH & 100 & - \\
EAT $70: 30$ & 100 & - & EAH 70:30 & 100 & - \\
EAT 50:50 & 100 & - & EAH 50:50 & 100 & - \\
EAT 30:70 & 100 & - & EAH 30:70 & 100 & - \\
\hline
\end{tabular}

$E=$ Errandi silk, $A=$ Acrylic, $T=$ Twill, $H=$ Herringbone

which depends on the density of the fiber in yarn. Further, a greater number of the twist in yarn means that fibers are more rigid because the fibers are close together. That means no freedom for movement of fiber so the formability is less (Rocco and Maurizio, 2010). The density of yarns were maximum in EA $30: 70$ yarn $\left(2.71 \mathrm{~g} / \mathrm{cm}^{3}\right)$ followed by controlled acrylic $\left(2.68 \mathrm{~g} / \mathrm{cm}^{3}\right)$ and minimum in controlled endi silk yarn $\left(2.08 \mathrm{~g} / \mathrm{cm}^{3}\right)$. The density is changing according to the number of twist in the yarn (Rocco and Maurizio, 2010).

\section{Fabric test results}

Cover factor, weight and thickness: In fabric, cover is considered as fraction of the total area covered by the component yarns (Behera et al. 2012). Cloth cover of the fabrics determines the appearance, handle, feel, permeability, and transparency, limits of pick insertion and texture of fabric. The analytical data pertaining to the cover factor and weight were tested and recorded in Table 3. From the table it was observed that the unions fabrics with herringbone weave were found to have maximum value in cloth covers than the controlled fabrics. Fabric cover factor of warp as well as weft depends on factors like yarn count, twist per inch, threads per inch etc. Similarly, the fabric weights of all the controlled samples with herringbone weave were in increasing trend in weight per square meter as compared to union fabrics. This variation in fabric weight may be due to the blend proportion and different weave structure of the test fabrics and as well as dense of the fabric. It is always assumed that thicker the fabric longer is its life. Properties like drapability, abrasion resistance; thermal insulation value of fabric depends on cloth thickness (Booth, 1968). From the Table 3, it could be elicited that a controlled fabric with herringbone weave shows maximum thickness compared with other union fabrics. The difference in thickness may be due to the fibre types, yarn twist, blend proportion and fabric structure.

Subjective evaluation of newly developed errandi union fabrics for market potentially 
Boruah, S. et al. / J. Appl. \& Nat. Sci. 10 (3): 925 - 930 (2018)

Table 8. Analysis of newly developed errandi-acrylic union fabrics for dress designs based on expert opinion (\%).

\begin{tabular}{|c|c|c|c|c|}
\hline \multirow{2}{*}{ Types of Fabric } & \multirow{2}{*}{ Developed Dresses } & \multicolumn{2}{|c|}{ Suitability (\%) } & \multirow{2}{*}{$\begin{array}{l}\text { Costing } \\
\text { (Approx.Rs.) }\end{array}$} \\
\hline & & Yes & No & \\
\hline EAT 70:30 & Princess Styline Frock with Cape & 100 & - & $2,935 /-$ \\
\hline EAH 70:30 & Waist Coat and Long Slack Pant & 100 & - & 7,983/- \\
\hline EAT 30:70 & Asymmetrical Shirt and Peg Pant & 100 & - & $4,250 /-$ \\
\hline EAH 30:70 & Slinky Dress with Circular Hemline Sleeves & 100 & - & $3,937 /-$ \\
\hline
\end{tabular}

$E=$ Errandi silk, $A=$ Acrylic, $T=$ Twill, $H=$ Herringbone

Table 9. Analysis of cost of blended yarns and union fabrics.

\begin{tabular}{|c|c|c|c|c|c|c|}
\hline \multirow[b]{2}{*}{ Proportion } & \multicolumn{2}{|l|}{ Yarns } & \multirow[t]{2}{*}{ Proportion } & \multicolumn{2}{|c|}{ Fabrics } & \multirow[b]{2}{*}{$\begin{array}{l}\text { Price in } \\
\text { Rs./mt* }\end{array}$} \\
\hline & $\begin{array}{l}\text { Quantity } \\
\text { (Kg) }\end{array}$ & $\begin{array}{l}\text { Price in } \\
\text { Rs./kg * }\end{array}$ & & $\begin{array}{l}\text { Weave } \\
\text { Type }\end{array}$ & $\begin{array}{l}\text { Quantity } \\
\text { (mt.) }\end{array}$ & \\
\hline Controlled & & & Controlled & & & \\
\hline Endi-Silk $100 \%$ & 1 & $3,000.00$ & Endi-Silk $100 \%$ & $\begin{array}{l}\text { Twill/ } \\
\text { Herringbone }\end{array}$ & 1 & 985.00 \\
\hline $\begin{array}{l}\text { Acrylic } 100 \% \\
\text { Blended }\end{array}$ & 1 & 500.00 & $\begin{array}{l}\text { Acrylic 100\% } \\
\text { Union }\end{array}$ & -Do- & 1 & 495.00 \\
\hline Endi Silk-Acrylic 70:30 & 1 & $2,250.00$ & Endi-Acrylic 70:30 & -Do- & 1 & 838.00 \\
\hline Endi Silk-Acrylic 50:50 & 1 & $1,750.00$ & Endi-Acrylic 50:50 & -Do- & 1 & 740.00 \\
\hline Endi Silk-Acrylic 30:70 & 1 & $1,250.00$ & Endi-Acrylic 30:70 & -Do- & 1 & 642.00 \\
\hline
\end{tabular}

*Include job charge

Respondents' opinion on general appearance of woven fabrics: Data on the consumer acceptability of errandi-acrylic union fabrics pertaining to general appearance have been presented in Table 4 .According to the experts' opinion. It was found that all the woven samples have good appearance except ET sample. 60 per cent Respondent stated fair appearance for ET sample.

Respondents' opinion on lustre of woven fabrics: The fabric lustre was assessed by considering three parameters of luster viz. high, moderate and low. Table 5 depicted the respondents' opinion on individual fabrics lustres. It was observed that cent percent of respondents found errandiacrylic blended union fabrics with two weaves were high in lustre.

Respondents' opinion regarding handle of woven fabrics: The handle of fabrics was assessed by considering three main parameters of handle viz., soft, crisp and stiffs. Table 6 narrates the respondents' opinion regarding fabric handle. It was interesting to observe that cent per cent respondents stated that all the test fabrics with twill and herringbone weaves were found soft to hand. No one rated any fabric as crisp or stiff.

Respondents' opinion regarding texture of woven fabrics: The texture of the fabric was assessed by respondents through physical touch and categorise into smooth and rough. Table 7 depicts the respondents' opinion on fabric texture of errandi-acrylic union fabrics. From the table it was found that cent per cent respondents stated that all the test fabrics with twill and herringbone weaves were smooth in texture. No one rated any sample as rough textured.

Analysis of newly developed errandi-acrylic union fabrics for dress designs based on expert opinion: Newly designed errandi-acrylic un- ion fabrics were used for developed different dresses based on expert opinioned regarding the suitability of the products. Opinion was taken from 100 respondents to assess the suitability of developed dresses. Table 8 revealed the suitability of developed dresses according to the types of fabrics and the approximate cost of each item. The raw material cost, cost of accessories used, labour cost and the $20 \%$ profit were taken into consideration for price calculation. Considering the cost and quality of products, 100 per cent respondents opined that the Asymmetrical Shirt and Peg Pant, Princess Styline Frock with Cape, Slinky Dress with Circular Hemline Sleeves, Waist Coat and Long Slack Pant were suitable.

Analysis of cost of blended yarns and errandiacrylic union fabrics: The cost analysis of developed errandi-acrylic blended yarns was presented in Table 9. It was cleared from the table that controlled errandi-acrylic silk was reasonably expensive compared to blended yarn. Further, it was interesting to note that the total cost of controlled errandi silk was maximum (Rs. 3,000/-) followed by errandi-acrylic 70:30 and errandi-acrylic 50:50. Similarly, it was inferred from the Table 9 that the total cost of errandi-acrylic union fabrics with twill and herringbone weaves of different proportion were got reduced comparison to controlled errandi silk (Rs. 985/-), which may be due to the utilization of greater amount of blend proportion of acrylic in weft. It was observed from the table that Cost $/ \mathrm{kg}$ of errandi silk yarn was higher than acrylic. On the whole it may be inferred that the cost of union fabrics were found to be inexpensive than the cent percent controlled errandi silk.

\section{Conclusion}

Errandi is known as the softest and warmest 
amongst all the silk and has immense potential for commercial exploitation. Value addition of errandi silk through blending, can lead to its diversified uses in apparel and home textiles while its current use is limited to export or in the silk industry. The study provides the information of aesthetic properties of Errandi with Acrylic union fabrics. Based on the properties, developed dresses may be found suitable for winter seasons. Thus, the newly designed Errandi silk with Acrylic union fabrics are unique, a new venture for the textile industry and Ericulturists. Errandi/Eri silk production can conveniently be under taken as a subsidiary occupation along with castor crop where castor is commercially cultivated for oil seeds and also a leisure time subsidiary activity by economically poor sections of the society. The knowledge generated by this study will be helpful to traditional spinners and weavers to diversify their product range that has the potential to enhance their domestic and export market.

\section{REFERENCES}

1. Bai H., Kumar S., Gihwika (2017). Entrepreneurship challenges and opportunities in India, Retrieved from www.conferanceworld.in.

2. Behera, Militky, Mishra and Kremenakova (2012). Modeling of Woven Fabrics Geometry and Properties, Woven Fabrics, Prof. Han-Yong Jeon (Ed.), ISBN: 978-953-51-0607-4, InTech, Available from: http://www.intechopen.com/books/woven-fabrics/ modeling-of-woven-fabrics-geometry-and-properties.

3. Booth, J. E. (1968). Principle of Textile Testing. Third Edn., Newnes Butterword, London. pp. 353-354.

4. Chakraborty P. and Ghosh D.(2016). The importance of handloom in India.Retrieved from https:// www.indianartloom.com/blogs/the-importance-ofhandloom-in-india/104151239-the-importance-ofhandloom-in-india.

5. Gupta, V. B., Rajkhowa, R. and Kothari, V. K. (2000). Physical characteristics and structure of Indian silk fibres. Indian Journal of Fibre \& Textile Research, 25: 14-19.

6. NPTEL (2014). Importance of Fiber Fineness . (http:// nptel.ac.in/courses/116102029/14).

7. Prakash, C., Ramakrishnan, G and Koushik, C. V. (2012). Effect of Blend ration on quality characteristics of Bamboo/Cotton blended ring spun yarn. Journal of Science and technology, 7(1):34-36.

8. Rieter (2018). Fiber count. Retrieved fromhttps:// www.rieter.com/cn/rikipedia/articles/rotor-spinning/ applications-engineering/fiber-properties/fiber-count/.

9. Rocco Furferi1 and Maurizio Gelli (2010). Yarn Strength Prediction: A Practical Model Based on Artificial Neural Networks .Hindawi Publishing Corporation Advances in Mechanical Engineerin, 6(3): 11.

10.Somashekar, T. H. (2003). Recent advances in eri silk spinning, weaving and future properties. Indian Silk, 41(12): 49-52.

11.Textile School (2018).Acrylic the artificial wool fibers. (https://www.textileschool.com > Fiber).

12. Vyshnavi V. P. and Nair S. Suja (2017). Handloom sector in India: a literature review of government report. International Research Journal of Management and Vommerce, 4(8):418-438. 